\title{
Erratum
}

\section{Deficiency of Parkinson's disease-related gene Fbxo7 is associated with impaired mitochondrial metabolism by PARP activation}

Marta Delgado-Camprubi, Noemi Esteras, Marc PM Soutar, Helene Plun-Favreau and Andrey Y Abramov

Cell Death and Differentiation (2017) 24, 2210; doi:10.1038/cdd.2017.175; published online 13 October 2017

Correction to: Cell Death and Differentiation (2017) 24, 120-131; doi:10.1038/cdd.2016.104; published online 30 September 2016

This article was originally published under a Creative Commons Attribution-NonCommercial-NoDerivs 4.0 license, but has now been made available under a Creative Commons Attribution 4.0 (CC BY) license.

The PDF and HTML versions of the paper have been modified accordingly. (c) (1) This work is licensed under a Creative Commons Attribution 4.0 International License. The images or other third party material in this article are included in the article's Creative Commons license, unless indicated otherwise in the credit line; if the material is not included under the Creative Commons license, users will need to obtain permission from the license holder to reproduce the material. To view a copy of this license, visit http:// creativecommons.org/licenses/by/4.0/

(C) The Author(s) 2017 